\title{
SISTEM PEMESANAN MAKANAN MENGGUNAKAN MIKROKONTROLER ATMEGA8535
}

\author{
Wilis Kaswidjanti, Dessyanto Boedi Prasetyo, Alamsyah \\ Jurusan Teknik Informatika UPN "Veteran" Yogyakarta \\ JI. Babarsari 2 Tambakbayan 55281 Telp (0274) 485323 \\ wilisk@yahoo.com, dess95@gmail.com, alam57ah@gmail.com
}

\begin{abstract}
Some restaurants are to develop the concept by placing the gazebo-gazebo that were located far apart. With a large area and a place to eat with the amount that more and more the restaurant must provide the waitresses in considerable amounts. Often when the waiter is still busy serving the other guests, then there will be visitors restaurants that can not be served well. In addition, the number of waiters that too many would economically burden the employers because it would result in expenditure will be even greater. Then it can be developed an information system involving hardware and software to apply the reservation system that can be done from the tables or places to eat at a restaurant. Systems built using hardware and software. The hardware is built by using the AVR microcontroller device comprising an IC (Integrated Circuit) which is supported by the power supply, as well as some passive and active components. Software on a microcontroller using $C$ language development tool using CodeVision of AVR. While the computer software using Visual Basic 6.0 programming language.

Food ordering system that created it can improve services for consumers in terms of booking. Buyers can make a reservation at the dinner table without going through the waitress who had approached the table and write whatever menu you want to order. Additional bookings can also be done through the table without leaving the place or the waiter.

Keywords : Food Booking System, Microcrontroller, Atmega8535

Beberapa rumah makan mengembangkan konsepnya dengan menempatkan gazebogazebo yang jaraknya berjauhan. Dengan area yang luas serta tempat makan dengan jumlah yang semakin banyak maka rumah makan harus menyediakan pramusaji dalam jumlah yang cukup banyak. Seringkali manakala pramusaji masih sibuk melayani pengunjung lain, maka akan ada pengunjung rumah makan yang tidak dapat terlayani dengan baik. Selain itu jumlah pramusaji yang terlalu banyak secara ekonomis akan memberatkan pengusaha karena akan mengakibatkan pengeluaran akan menjadi semakin besar.

Maka dapat dikembangkan suatu sistem informasi yang melibatkan perangkat keras dan perangkat lunak untuk mengaplikasikan sistem pemesanan yang dapat dilakukan dari mejameja atau tempat-tempat makan pada suatu rumah makan. Sistem dibangun dengan menggunakan perangkat keras dan perangkat lunak. Perangkat keras dibangun dengan menggunakan perangkat mikrokontroler AVR yang terdiri dari suatu IC (Integrated Circuit) yang didukung oleh catu daya, serta beberapa komponen pasif dan aktif. Perangkat lunak pada mikrokontroler menggunakan bahasa $\mathrm{C}$ dengan development tool menggunakan CodeVision dari AVR. Sedangkan perangkat lunak komputer menggunakan bahasa pemrograman Visual Basic 6.0.

Sistem pemesanan makanan yang dibuat ini dapat meningkatkan pelayanan bagi konsumen dari segi pemesanan. Pembeli dapat melakukan pemesanan pada meja makan tanpa melalui pramusaji yang harus menghampiri meja makan dan menulis menu apa saja yang akan dipesan. Pemesanan tambahan dapat juga dilakukan melalui meja tanpa meninggalkan tempat atau memanggil pramusaji.

Kata kunci : Sistem Pemesanan Makanan, Mikrokontroler, Atmega8535
\end{abstract}

\section{PENDAHULUAN}

Perkembangan ilmu pengetahuan dan teknologi yang sangat pesat ini merupakan salah satu dampak dari meningkatnya taraf hidup manusia. Untuk itu setiap manusia menginginkan adanya kemudahan dan kecepatan dalam memenuhi setiap kebutuhannya. Oleh karena itu, dikembangkan suatu cara yang mampu mengatasi keinginan tersebut seiring dengan 
perkembangan peradaban teknologi saat ini. Salah satu cara penerapannya adalah dalam bidang rumah makan.

Rumah makan yang merupakan sebuah usaha yang menyajikan hidangan kepada masyarakat dan menyediakan tempat untuk menikmati hidangan itu serta menetapkan tarif tertentu untuk makanan dan pelayanannya, terus mengalami perkembangan. Salah satu faktor penyebab berkembang cepatnya rumah makan adalah pertumbuhan penduduk yang semakin banyak. Dengan semakin banyaknya jumlah penduduk, maka semakin banyak pula kebutuhan pangan yang harus disediakan.

Perkembangan rumah makan yang pesat ini menimbulkan persaingan yang ketat, dimana pelaku bisnis dituntut untuk dapat memberikan yang terbaik bagi konsumen. Pemenuhan harapan konsumen akan mendatangkan kepuasan konsumen dan keuntungan bagi para pelaku bisnis. Salah satu usaha dalam meningkatkan pelayanan bagi konsumen adalah dari segi pemesanan. Cara konvensional yang menggunakan jasa manusia untuk meminta menu pesanan dari pembeli dapat diganti dengan menggunakan alat pemesanan yang langsung dapat digunakan dari meja pembeli. Sehingga menu pesanan dari pembeli ini dapat langsung diketahui oleh petugas rumah makan melalui sebuah Personal Computer (PC).

\section{BAHAN DAN METODE}

\subsection{Sistem}

Sistem adalah sekumpulan elemen yang saling terkait atau terpadu yang dimaksudkan untuk mencapai tujuan (Kadir,2002). Ada beberapa elemen yang membentuk sebuah sistem, yaitu : tujuan, masukan, keluaran, proses, mekanisme pengendalian dan umpan balik. Sistem juga berinteraksi dengan lingkungan dan memiliki batas (Kadir, 2002).

\subsection{Metode Pengembangan Sistem}

Metode yang digunakan dalam pengembangan sistem adalah metode Waterfall (siklus air terjun). Metode ini dikenal pula dengan nama "Classic Life Code" (Pressman, 2002). Tahapan-tahapan dalam siklus air terjun (waterfall) adalah rekayasa, analisis, desain, implementasi, pengujian, pemeliharaan

\subsection{Diagram Alir Data}

Data Flow Diagram (DFD) adalah sebuah teknik grafis yang menggambarkan aliran informasi dan transformasi yang diaplikasikan pada saat data bergerak dari input menjadi output (Pressman, 2002).

\subsection{Basis Data}

Basis data terdiri atas 2 kata, yaitu Basis dan Data. Basis diartikan sebagai markas atau gudang. Sedangkan data adalah representasi fakta dunia nyata yang mewakili suatu objek seperti manusia, barang, hewan dan lain-lain. Jadi basis data dapat didefinisikan sebagai kumpulan data yang saling berhubungan yang disimpan secara bersama sedemikian rupa dan tanpa pengulangan yang tidak perlu, untuk memenuhi berbagai kebutuhan (Fathansyah, 2007) :

\subsection{Komunikasi Data}

Komunikasi data berkaitan dengan komunikasi mesin ke mesin seperti misalnya terminal ke komputer, dan komputer ke komputer. Sebagian besar mesin yang mempunyai kecerdasan menggunakan sinyal listrik digital maka komunikasi termudah juga menggunakan sinyal digital.

\subsection{Mikrokontroler}

Mikrokontroler adalah suatu terobosan teknologi mikroprosesor dan mikrokomputer, yang mana teknologi ini adalah teknologi semikonduktor dengan kandungan transistor yang lebih banyak, namun hanya membutuhkan ruang yang kecil serta dapat diproduksi secara masal (dalam jumlah banyak) sehingga harganya menjadi lebih murah (Budiharto, 2005).

Mikrokontroler ini kemampuan digitalnya menirukan fungsi otak manusia, sehingga meliputi fungsi atau instruksi aritmatika (berhitung), logika (mempertimbangkan suatu kondisi), dan memori. Mikrokontroler ini berbeda halnya dengan mikroprosesor yang hanya pemrosesannya terdiri dari Central Processing Unit (CPU) dan register-register, tanpa memori, tanpa $\mathrm{I} / \mathrm{O}$, dan peripheral yang dibutuhkan oleh suatu sistem supaya dapat bekerja.

Pada sistem yang akan dibuat dalam laporan ini menggunakan Mikrokontroler ATMega8535. Mikrokontroler ATMega8535 adalah sebuah mikrokontroler yang terdiri dari 8 bit dengan low power dan performa tinggi. Termasuk dalam mikrokontroler AVR yang memiliki 
arsitektur RISC 8 bit, dimana semua instruksi dikemas dalam kode 16-bit dan sebagian besar instruksi dieksekusi dalam satu siklus clock.

\subsection{LCD $16 \times 2$ Karakter}

LCD (Liquid Crystal Display) adalah suatu penampil dari bahan cairan cristal yang dalam pengoperasiannya digunakan sistem dot matriks (Budiharto,2005). LCD banyak digunakan sebagai displai dari alat-alat elektronika seperti kalkulator, jam digital dan sebagainya.

LCD yang digunakan pada alat ini adalah LCD M1632, LCD ini merupakan modul LCD dengan tampilan $16 \times 2$ baris dengan konsumsi daya yang rendah. Modul ini dilengkapi dengan LCD Mikrokontroler HD44780 buatan Hitachi yang berfungsi sebagai pengendali. LCD ini mempunyai CGRAM (Character Generator Random Access Memory) yang merupakan merupakan memori tempat karakter yang ditampilkan, dan DDRAM (Display Data Random Access Memory) yang merupakan memori untuk menggambarkan pola sebuah karakter dimana bentuk dari karakter dapat diubah-ubah sesuai keinginan. Namun memori ini akan hilang saat power supply tidak aktif, sehingga pola karakter akan hilang.

\subsection{Pemrograman Bahasa C}

Bahasa pemrograman $\mathrm{C}$ merupakan salah satu bahasa pemrograman komputer. Dibuat pada tahun 1972 oleh Dennis Ritchie untuk Sistem Operasi Unix di Bell Telephone Laboratories. Meskipun $\mathrm{C}$ dibuat untuk memprogram sistem dan jaringan komputer namun bahasa ini juga sering digunakan dalam mengembangkan software aplikasi. C juga banyak dipakai oleh berbagai jenis platform sistem operasi dan arsitektur komputer, bahkan terdapat beberepa compiler yang sangat populer telah tersedia. C secara luar biasa mempengaruhi bahasa populer lainnya, terutama $\mathrm{C}++$ yang merupakan extensi dari C (Susabda, 2006).

\section{HASIL DAN PEMBAHASAN}

Perangkat lunak yang digunakan harus dapat mengintegrasikan seluruh peralatan pendukung yang digunakan dalam sistem pemesan makanan ini. Mikrokontroller harus mampu mengolah data masukkan yang selanjutnya dikirim ke PC untuk mengetahui instruksi data.

\subsection{Diagram Blok Sistem}

Pada rancang bangun perangkat pemesanan makanan di rumah makan ini digunakan tahapan dan cara-cara yang terstruktur sehingga mendapatkan hasil yang baik. Perangkat yang akan dibuat secara umum terdiri dari 2 sistem yaitu sistem mikrokontroler dan sistem komputer. Sistem mikrokontroler meliputi perangkat reporting yang diletakkan di meja, sedangkan sistem komputer meliputi software yang dipergunakan untuk menganalisa data pengiriman dari reporting module yang ada di meja. Berikut ini digambarkan diagram blok dari seluruh sistem yang akan dibuat :

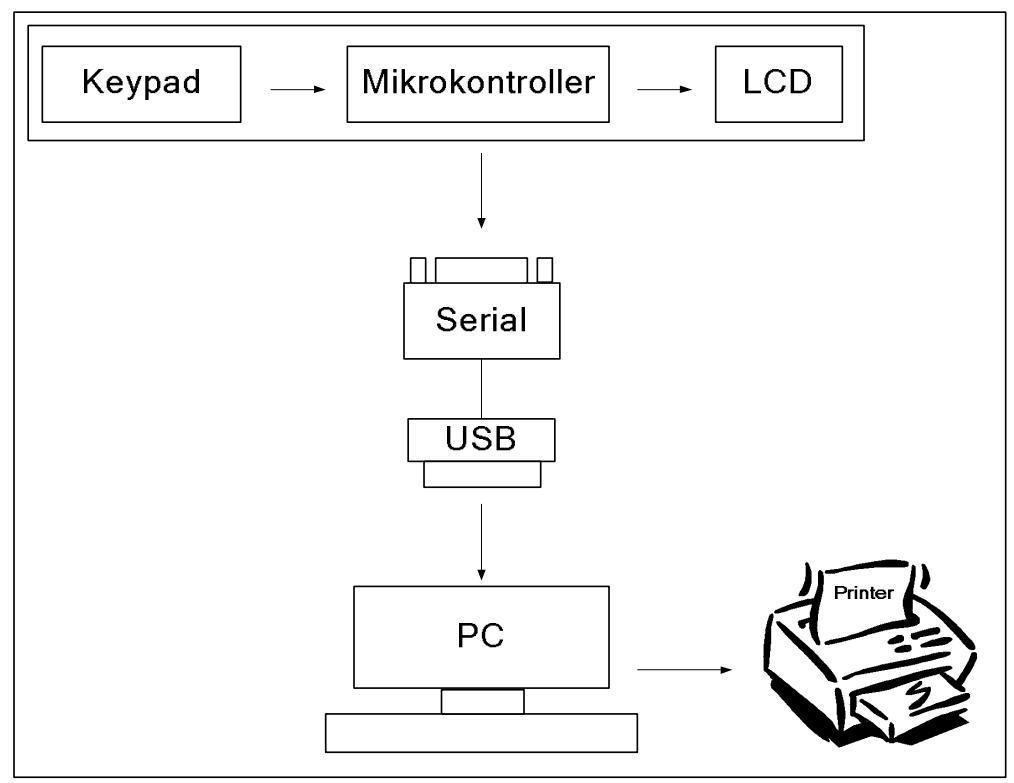

\subsection{Data Flow Diagram}

Gambar 1 Diagram Blok Sistem

Data Flow Diagram adalah model logika data atau proses yang dibuat untuk menggambarkan darimana asal data dan kemana tujuan data yang keluar dari sistem, dimana data disimpan, proses apa yang menghasilkan data tersebut dan interaksi data yang tersimpan. 
Data flow diagram juga dapat digunakan untuk menggambarkan sistem pada setiap tingkatan dan dapat dipecah-pecah. Keuntungan dari penggunaan DFD adalah dapat menggambarkan sistem dari level yang paling tinggi ke level yang paling rendah. DFD juga membantu untuk mendokumentasikan proses aliran data sistem. Langkah awal dengan membuat diagram konteks atau DFD level 0 sebagai gambaran sistem secara global.

DFD level 0 merupakan level yang merepresentasikan jalannya proses yang terjadi di dalam sistem atau dapat disebut sebagai diagram konteks. Adapun DFD level 0 pada sistem ini dapat digambarkan sebagai berikut :

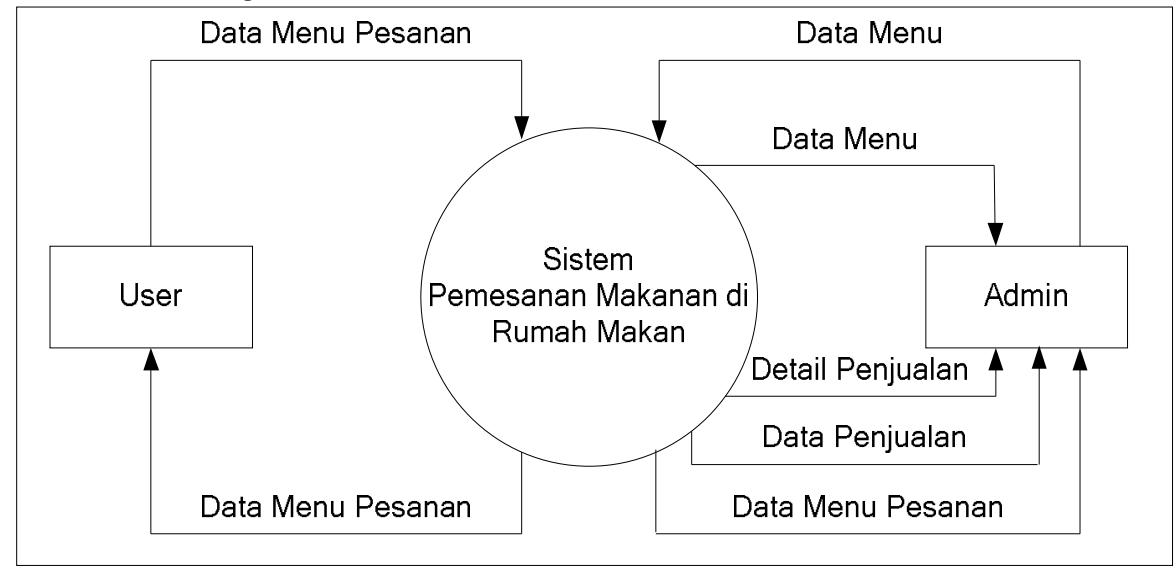

\section{Gambar 2 DFD Level 0}

Pada DFD level 0 menggambarkan seluruh sistem dari aplikasi yang akan dibangun, terdapat dua entitas luar yaitu user dan admin.

Langkah selanjutnya adalah DFD level 1 yang merupakan pengembangan atau pemecahan proses lebih lanjut dari DFD 0.

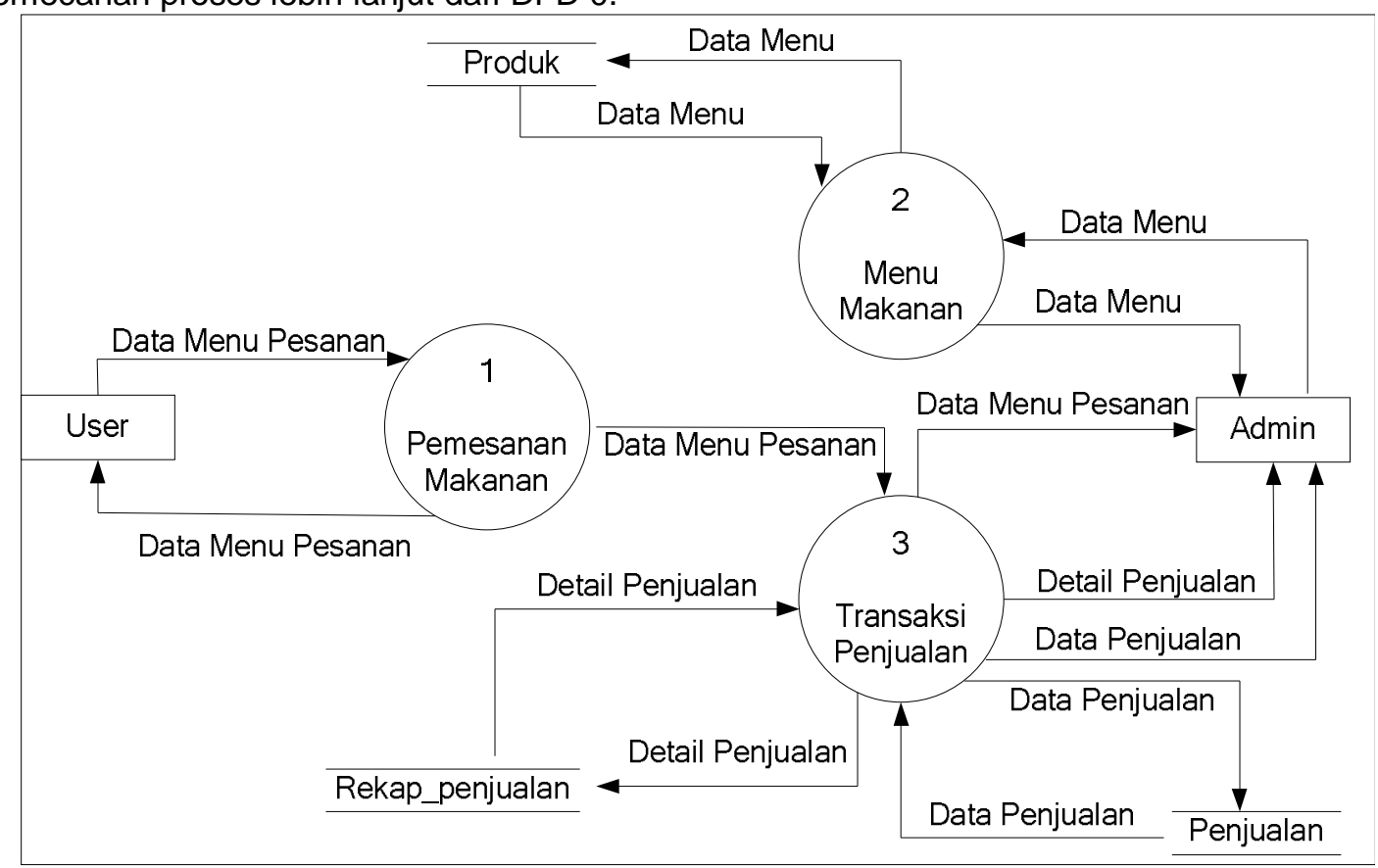

\subsection{Perancangan Entity-Relationship Diagram (ERD)}

Secara keseluruhan struktur logika dari basis data dapat digambarkan secara grafik dengan menggunakan Entity Relationship Diagram (ERD). Rancangan ERD dalam sistem ini dapat dilihat pada gambar 3.4 berikut : 


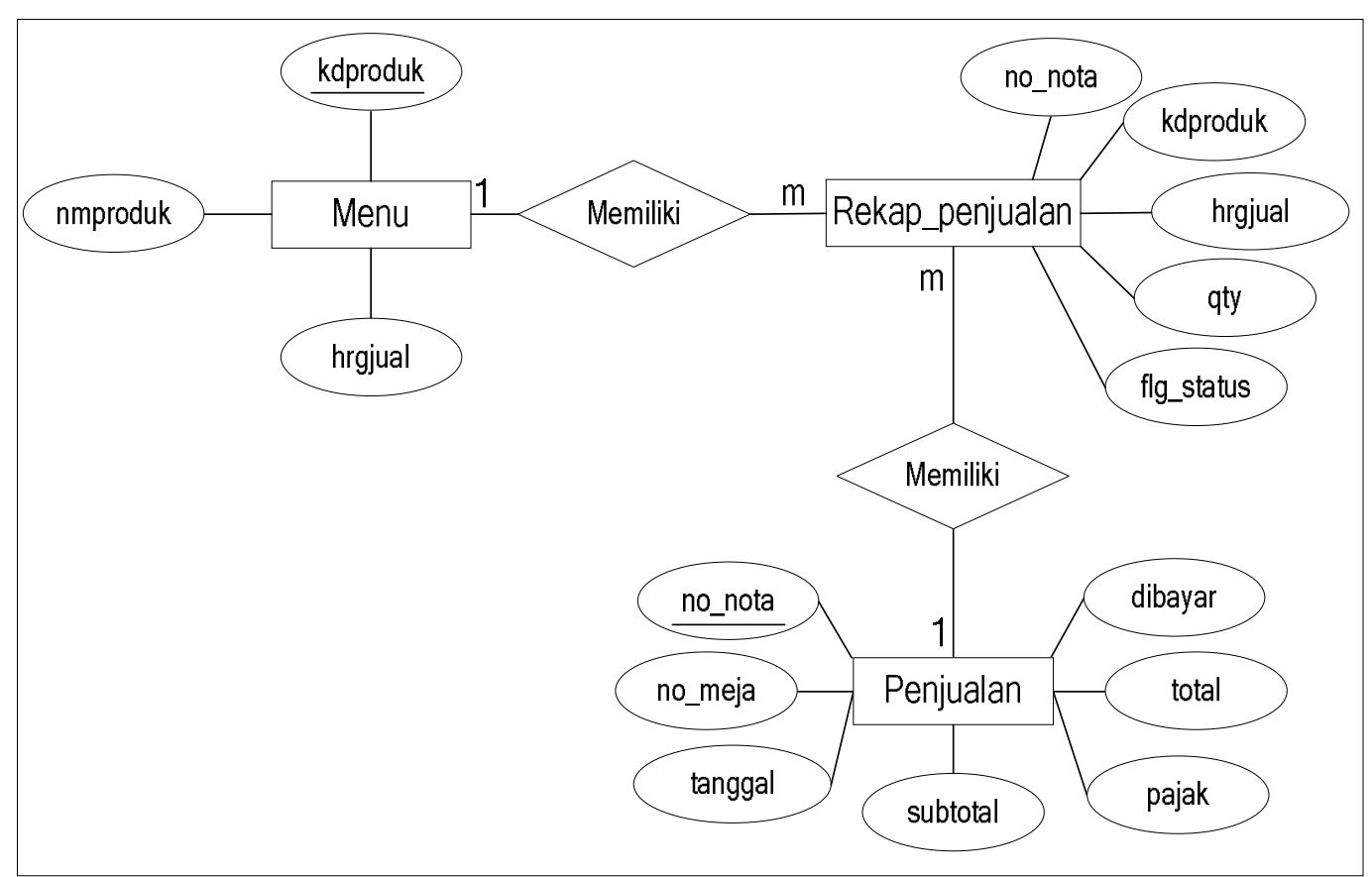

Gambar 4 Entity Relationship Diagram

\subsection{Rancangan Menu Admin}

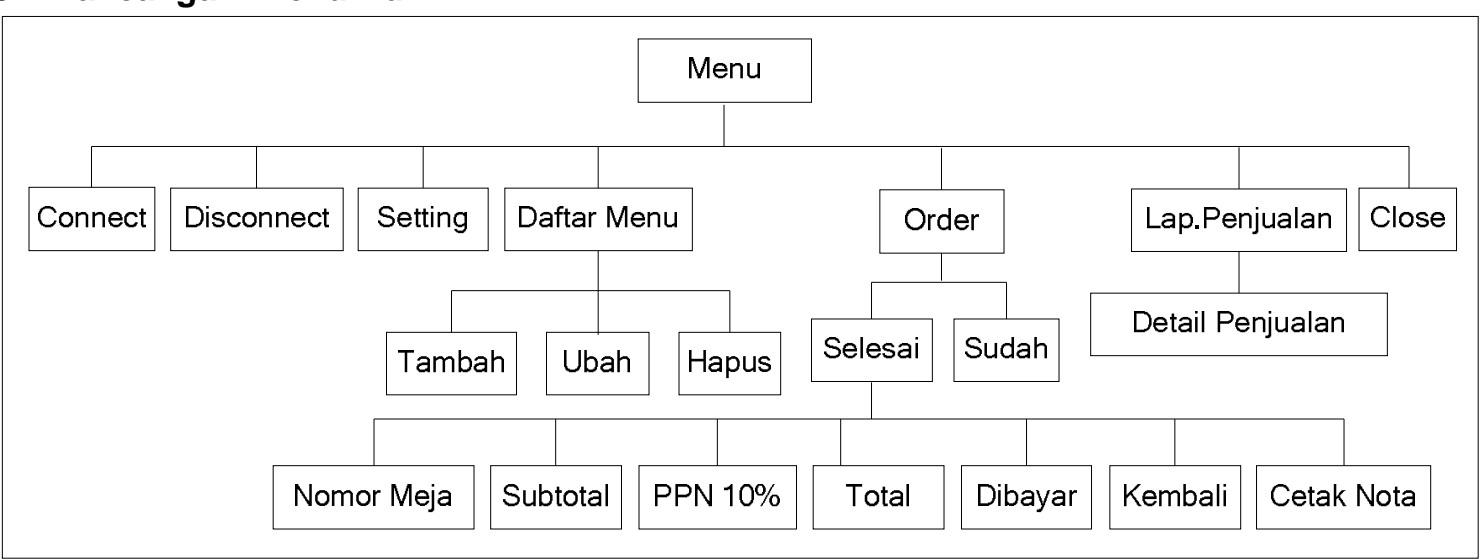

Menu Connect

Menu Disconnect

Menu Setting

Menu Daftar Menu

Menu Selesai

Menu Lap.Penjualan

Menu item terjual

Menu Close

\section{Gambar 5 Rancangan Menu Admin}

: Berfungsi untuk mengkoneksikan hardware.

Dipakai sebagai pemutus koneksi hardware.

: Memanggil Form Hardware.

Menampilkan Form Produc View.

: Mengakhiri transaksi masing - masing meja, yang kemudian akan menampilkan Form Finish.

: Menyimpan semua transaksi yang terjadi.

Memberi data jumlah semua item yang terjual.

: Menutup program.

\subsection{Tampilan Form Main}

Form main merupakan tampilan utama, dalam program aplikasi ini dapat dilihat dari meja mana pemesanan dilakukan, menu apa saja yang dipesan, berapa jumlah porsi yang pesan, harga per item dan harga subtotal pesanan yang dilakukan, juga status pesanan sudah diproses atau belum. 


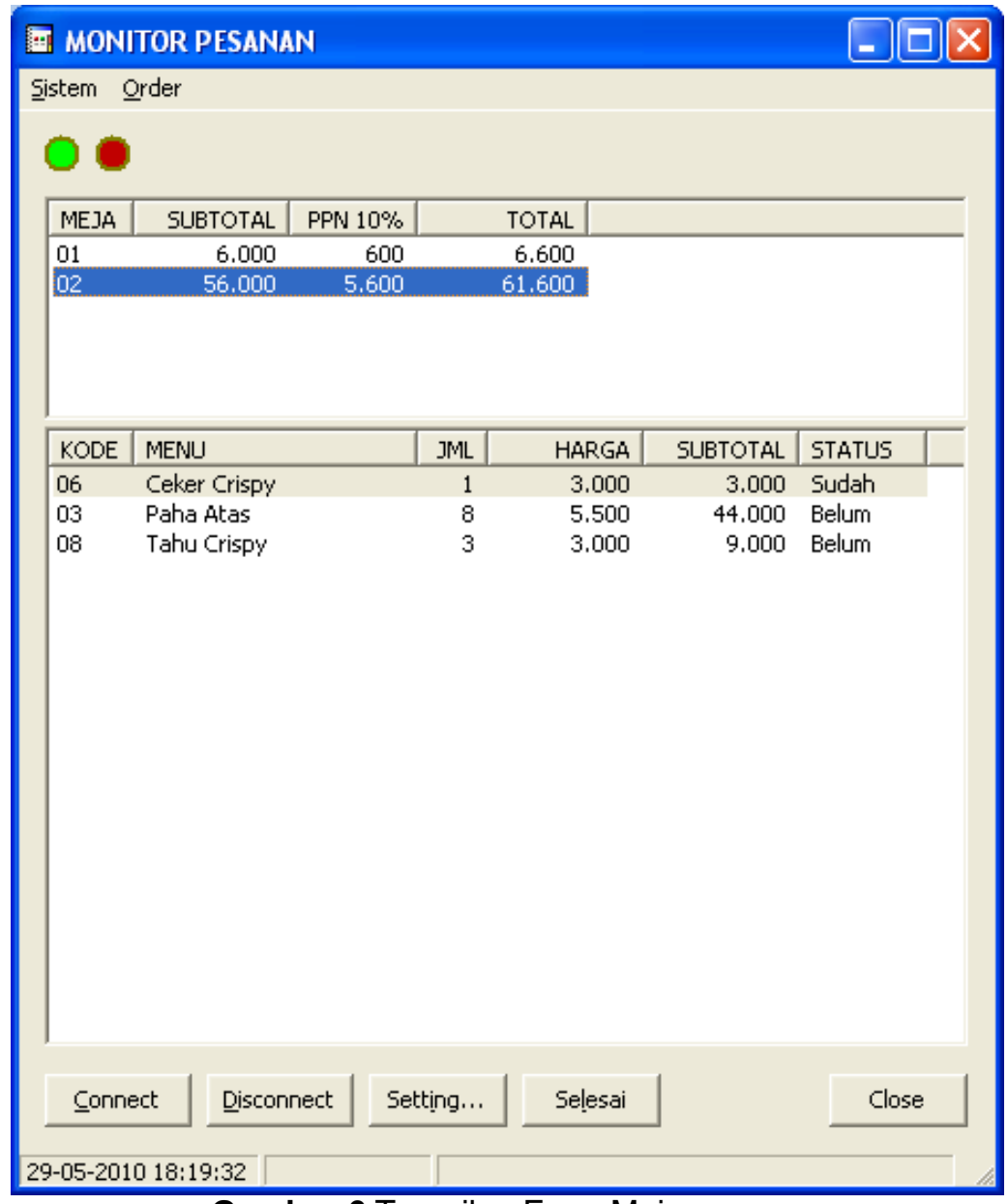

\section{KESIMPULAN}

\section{Gambar 6 Tampilan Form Main}

Sistem pemesanan makanan di rumah makan menggunakan mikrokontroler atmega8535 memberikan fasilitas utama yaitu dapat melakukan pemesanan pada meja makan tanpa melalui pelayan yang harus menghampiri meja makan dan menulis menu apa saja yang akan dipesan. Pemesanan tambahan dapat juga dilakukan melalui meja tanpa meninggalkan tempat atau memanggil pelayan. Dari pengujian dapat disimpulkan bahwa pada saat pemesanan makanan dilakukan maka sistem akan mengirimkan data pemesanan melalui port serial dan ditampilkan pada komputer, hasil input data yang ada telah sesuai dengan apa yang ditampilkan pada komputer.

\section{DAFTAR PUSTAKA}

Budiharto, W., 2005, Perancangan Sistem dan Aplikasi Mikrokontroler, Elex Media Komputindo, Jakarta

Fathansyah, 2007, Basis Data, Informatika, Bandung

Heryanto, M.A., Wisnu, P., 2008, Pemrograman Bahasa C Untuk Mikrokontroler ATMEGA8535, Andi, Yogyakarta

Kadir, Abdul, 2002, Pengenalan Sistem Informasi, Andi, Yogyakarta

Prasetia, Catur, Retna, dan Widodo E., 2004, Teori dan Praktek Interfacing Port Paralel dan Port Serial Komputer dengan Visual Basic 6.0, Andi, Yogyakarta

Pressman, R.S., 2002, Rekayasa Perangkat Lunak Pendekatan Praktisi (BUKU SATU), Penerbit Andi, Yogyakarta

Thopson, Susabda, 2006, Pengantar Bahasa C, Salemba Infotek, Jakarta 